\title{
Lithium-boro-tellurite glasses with ZnO additive: Exposure Buildup Factors (EBF) and Nuclear Shielding Properties
}

\author{
Gülfem Süsoy ${ }^{1 *}$ \\ ${ }^{1}$ Istanbul University, Faculty of Science, Department of Physics, 34134, Istanbul, Turkey (ORCID: 0000-0002-3760-1999)
}

(First received 3 February 2020 and in final form 12 March 2020)

(DOI: 10.31590/ejosat.697254)

ATIF/REFERENCE: Süsoy, G. (2020). Lithium-boro-tellurite glasses with ZnO additive: Exposure Buildup Factors (EBF) and Nuclear Shielding Properties. European Journal of Science and Technology, (18), 531-544.

\begin{abstract}
The effect of $\mathrm{ZnO}$ increment on lithium boro tellurite $\left(\mathrm{Li}_{2} \mathrm{O}-\mathrm{B}_{2} \mathrm{O}_{3}-\mathrm{P}_{2} \mathrm{O}_{5}-\mathrm{ZnO}\right)$ glass structure was investigated with the study of gamma and neutron attenuation properties. The gamma-ray shielding effectiveness of materials can be understood with the help of several different shielding parameters that play an important role in understanding the shielding capacities of the material. The mass attenuation coefficients $(\mu / \rho)$ for $\mathrm{Li}_{2} \mathrm{O}_{-} \mathrm{B}_{2} \mathrm{O}_{3}-\mathrm{P}_{2} \mathrm{O}_{5}-\mathrm{ZnO}$ glass samples were calculated by using the XCOM program based on the DOS-based compilation XCOM. To compare the theoretical and simulation results of the mass attenuation coefficients of the samples, MCNPX (Monte Carlo N-Particle) simulation code was handled with the XCOM program in the energy range of $0.02 \mathrm{MeV}-20 \mathrm{MeV}$. In addition, effective atomic numbers $\left(Z_{\mathrm{eff}}\right.$, electron densities $\left(\mathrm{N}_{\mathrm{el}}\right)$, effective removal cross-section $\left(\Sigma_{\mathrm{R}}\right)$ and the transmission factor $(\mathrm{TF})$ for sample glasses, have also been examined in that energy range. In addition to these parameters the Half-value layer (HVL), tenth value layer (TVL) and also mean free path (MFP) values were calculated by using the $\mu / \rho$. Moreover, exposure buildup factors (EBF) was calculated at $0.015-15 \mathrm{MeV}$ up to $15 \mathrm{mfp}$ by utilizing the G-P fitting approach. The glass having $20 \mathrm{~mol} \% \mathrm{ZnO}$ was found to has better gammaray shielding properties among the investigated glass samples. As a result, sample ZL5 among studied glasses has marvelous attenuation effectiveness whereas sample ZL1 has the best neutron radiation shielding performance. The outcomes of the present extended research can provide significant information for the comparison of new generation shielding materials with conventional shielding materials used in ionizing radiation facilities.
\end{abstract}

Keywords: $\mathrm{ZnO}$; gamma shielding; EBF; neutron shielding; MCNPX;

\section{ZnO Katkılı Lityum-Boro Tellürit Camlar: Maruz Kalma Faktörü (EBF) ve Nükleer Zırhlama Özellikleri}

\begin{abstract}
Özet
Lityum boro tellürit $\left(\mathrm{Li}_{2} \mathrm{O}-\mathrm{B}_{2} \mathrm{O}_{3}-\mathrm{P}_{2} \mathrm{O}_{5}-\mathrm{ZnO}\right)$ cam yapısı üzerinde $\mathrm{ZnO}$ katkısının etkisi, gama ve nötron zayıflatma özelliklerinin incelenmesi ile araştırılmıştır. Malzemelerin gama ışını zırhlama etkinliği, malzemenin zırhlama kapasitelerinin anlaşılmasında önemli bir rol oynayan birkaç farklı zırhlama parametrenin yardımıyla anlaşılabilir. $\mathrm{Li}_{2} \mathrm{O}-\mathrm{B}_{2} \mathrm{O}_{3}-\mathrm{P}_{2} \mathrm{O}_{5}-\mathrm{ZnO}$ cam örnekleri için kütle zayıflatma katsayıları $(\mu / \rho)$, DOS-tabanlı XCOM'u temel alan XCOM programı kullanılarak hesaplanmıştır. Numunelerin kütle zayıflatma katsayılarının teorik ve simulasyon sonuçlarını karşılaştırmak için, $0.02 \mathrm{MeV}$ - $20 \mathrm{MeV}$ enerji aralığında XCOM programı ile MCNPX (Monte Carlo N-Parçacık) simulasyon kodu kullanıldı. Ek olarak, etkili atom numarası (Zeff), elektron yoğunluğu (N $\mathrm{N}_{\mathrm{el}}$ ), etkili çıkarma tesir kesiti $\left(\Sigma_{R}\right)$ ve numune camları için iletim faktörü (TF) değerleri de bu enerji aralığında incelenmiştir. Bu parametrelere ek olarak Yarı-değer kalınlığı (HVL), onuncu değer kalınlığı (TVL) ve ayrıca ortalama serbest yol (MFP) değerleri $\mu / \rho$ kullanılarak hesaplanmıştır. Ayrıca G-P fitleme yaklaşımı kullanılarak maruz kalma faktörü (EBF) değerleri de 0.015-15 MeV'de 15 mfp'ye kadar hesaplanmıştır. İncelenen cam örnekleri arasından \% 20 mol ZnO katkısına sahip cam örneğinin daha iyi gama 1şını koruyucu özelliklerine sahip olduğu bulunmuştur. Sonuç olarak, incelenen cam örnekleri arasından ZL5, en iyi zayıflatma etkinliğine sahipken ZL1 cam örneği, en iyi nötron radyasyon zırhlama performansına sahiptir. Mevcut araştırmanın bu yeni sonuçları, yeni nesil zırhlama
\end{abstract}

\footnotetext{
* Corresponding Author: Istanbul University, Faculty of Science, Department of Physics, 34134, Istanbul, Turkey, ORCID: 0000-0002-3760-1999, glfmsusoy972@gmail.com
} 
malzemeleri ile iyonlaştırıcı radyasyon tesislerinde kullanılan geleneksel zırhlama malzemelerinin karşılaştırılması için önemli bilgiler sağlayabilir.

Anahtar Kelimeler: ZnO; gamma zırhlama; EBF; nötron zırhlama; MCNPX.

\section{Introduction}

In recent years, an increase has been observed in nuclear research laboratories and nuclear power plants. On the other hand, with the spread of radiation diagnosis-treatment methods, the number of personnel exposed to high energy radiation is increasing, especially in the field of medicine. Glasses, one of the radiation shielding materials, is a new groundbreaking application. These glasses have a wide range of applications such as nuclear medicine, radiology, imaging units, radiation oncology and nuclear physics research laboratories etc. They are produced especially because they absorb the photon radiation well. A familiar inorganic glass-composing oxide, $\mathrm{B}_{2} \mathrm{O}_{3}$ has a low melting point and well thermal stability. Between heavy-metal oxide based glasses, tellurite-glasses become prominent with the possibility of modifying the glass composition with a large number of components, which can contain rare-earth elements (REE), highly polarized ions $\left(\mathrm{Pb}^{2+}, \mathrm{Bi}^{3+}, \mathrm{Tl}^{4+}\right)$ and transition-metal oxides with a high proportion. And thus offers better non-linear optical properties [1-2]. Tellurite glasses; thanks to the high refractive index $(>2)$, high insulating constants, high electrical conductivity, superior mechanical properties, high chemical and thermal stabilization, low glass-transition and defrost temperatures are suitable for optoelectronic applications, for example, optical fibers, microlens, data storing devices, lasers, sensors, optical imager, optic modulators and spectroscopic devices [3-6]. These important features promote the research specialist and engineers for using tellurite-glasses in several applications. $\mathrm{TeO}_{2}$ is a conditional glassmaker; does not have the ability to make glass alone. Therefore, it makes the glass by adding a small amount of a second constituent (modifier) for example heavy metal oxide, alkali oxide or halide to modify the network structure [1]. Adding a small amount of $\mathrm{TeO}_{2}$ to the borate glass system increases the stabilization and the capability to form a glass. Lithium oxide $\left(\mathrm{Li}_{2} \mathrm{O}\right)$ plays a role in modifying the glass network structure. By adding $\mathrm{Li}_{2} \mathrm{O}$ to the boro telluride glass system, mechanical, physical, transport and structural features are varied. Oxide glasses with $\mathrm{Li}_{2} \mathrm{O}$ are commonly used in solar cell applications, solid-state batteries, and superionic conductors. Studies on boro-telluride glass samples having ZnO are quite exotic owing to their eminent refractive point and optical ethereality [7]. As a promising material for fiber optic technology, lasers, solar-cells and sensor studies, boro tellurite zinc glasses are largely used in the application of gas sensors, optoelectronic memory changing tools and optical waveguide practices [8-10]. Previous studies in literature on the Tellurite glass samples are $\mathrm{TeO}_{2}-\mathrm{ZnO}_{\mathrm{Dutta}}$ et al. [11], $\mathrm{TeO}_{2}-\mathrm{Li}_{2} \mathrm{O}-$ $\mathrm{ZnO}$ Mohammed et al. [12], $\mathrm{TeO}_{2}-\mathrm{Li}_{2} \mathrm{O}-\mathrm{B}_{2} \mathrm{O}_{3}$ Saddeek et al. [13], $\mathrm{ZnO}-\mathrm{B}_{2} \mathrm{O}_{3}-\mathrm{P}_{2} \mathrm{O}_{5}-\mathrm{TeO}_{2}$ Mosner et al. [14]. Ghada E. El Falaky et al. [15] examined the impact of $\mathrm{ZnO}$ on the mechanical and physical features of borate glass systems. Y.B. Saddeek et al. [16] examined mechanical, thermal and structural features of $\mathrm{B}_{2} \mathrm{O}_{3}-\mathrm{TeO}_{2}-\mathrm{Bi}_{2} \mathrm{O}_{3}$ and $\mathrm{Li}_{2} \mathrm{O}-\mathrm{TeO}_{2}-\mathrm{B}_{2} \mathrm{O}_{3}$ [17] glasses. G.Lakshminarayana et al. [18] worked on the $\mathrm{TeO}_{2}-\mathrm{B}_{2} \mathrm{O}_{3}-\mathrm{BaO}-\mathrm{ZnO}-\mathrm{Na}_{2} \mathrm{OEr}_{2} \mathrm{O}_{3}-\mathrm{Pr}_{6} \mathrm{O}_{11}$ glass samples for gamma ray shielding features by using the thermal and vibrational spectroscopic studies. N. Elkhoshkhany et al. [19] examined the constitutive and optical behavior of $\mathrm{TeO}_{2}-\mathrm{Li}_{2} \mathrm{O}_{-} \mathrm{ZnONb}_{2} \mathrm{O}_{5}-$ $\mathrm{Er}_{2} \mathrm{O}_{3}$ glass system. S. Rani et al. [20] examined the role of $\mathrm{Li}_{2} \mathrm{O}$ on the physical, optical and constitutive features of zinc boro-tellurite glasses. M. G. Dong et al. [21] examined the role of $\mathrm{Li}_{2} \mathrm{O}$ on the gamma radiation shielding properties of lithium-zinc-bismuth-borate glass system using the XCOM program and MCNPX code. The purpose of this study is to estimate the role of $\mathrm{ZnO}$ on the gamma shielding parameters in lithium boro-tellurite glasses. Molar fractions and the densities of the glass samples mentioned in this work are listed in Table 1 [22]. We estimate the mass attenuation coefficients $(\mu / \rho)$, total electronic $\left(\sigma_{t, e l}\right)$, atomic $\left(\sigma_{t, a}\right)$ and molecular $\left(\sigma_{t, m}\right)$ cross sections, effective atomic numbers (Zeff), electron densities $(\mathrm{Nel})$ of the stated glass samples. The estimated values have been likened with the theoretical ones computed with the XCOM program. Some concerning parameters effective removal cross-section $\left(\Sigma_{\mathrm{R}}\right)$ and the transmission factor (TF) for sample glasses have also been examined in the energy range from $0.02 \mathrm{MeV}$ to $20 \mathrm{MeV}$. The outcomes of the present extended research can provide significant information for the comparison of new generation shielding materials with conventional shielding materials used in ionizing radiation facilities.

Table 1. Chemical Properties of the Investigated Glasses

\begin{tabular}{cccccc}
\hline $\begin{array}{c}\text { Sample } \\
\text { Code }\end{array}$ & $\mathbf{B}_{2} \mathbf{O}_{3}$ & $\mathbf{Z n O}$ & $\mathbf{T e O}_{2}$ & $\mathbf{L i}_{2} \mathbf{O}$ & $\begin{array}{c}\text { Density } \\
\left(\mathbf{g} / \mathbf{c m}^{3}\right)\end{array}$ \\
\hline ZL1 & 60 & 0 & 10 & 30 & 3.32 \\
$Z L 2$ & 60 & 5 & 10 & 25 & 3.08 \\
$Z L 3$ & 60 & 10 & 10 & 20 & 3.14 \\
$Z L 4$ & 60 & 15 & 10 & 15 & 3.07 \\
$Z L 5$ & 60 & 20 & 10 & 10 & 3.44
\end{tabular}




\section{Material and Method}

\subsection{MCNPX and WinXCom Program}

The issue of radiation absorption in the fields of nuclear energy and medicine remains important. There are various equations and studies in the literature for the absorption of $\alpha, \beta$ radiations and $\mathrm{n}$ (neutron), $\mathrm{p}$ (proton) particles. MCNPX is a very useful program and has a general object Monte Carlo N-Particle code and used for the transmission of model radiation such as Gamma-ray, X-ray, neutron or electron radiations via matter [23]. In this study, $\mathrm{NaI}(\mathrm{Tl})$ detector was used to detect gamma rays and the verification with the MCNPX code was done by Tekin [24]. The simulation setup used in the study is shown in Figure 1. This setup consists of five different elements. These are isotropic radioactive spot source, $\mathrm{Pb}$ collimator for original radiation rays, glass sample, $\mathrm{Pb}$ blocks for protection against scattered photons, and $\mathrm{NaI}(\mathrm{Tl})$ detector. In order to calculate the $\mu / \rho$ of the sample glasses in this study, the XCOM program [25, 26] together with the MCNP program was also used by using the fractions stated in Table 1.
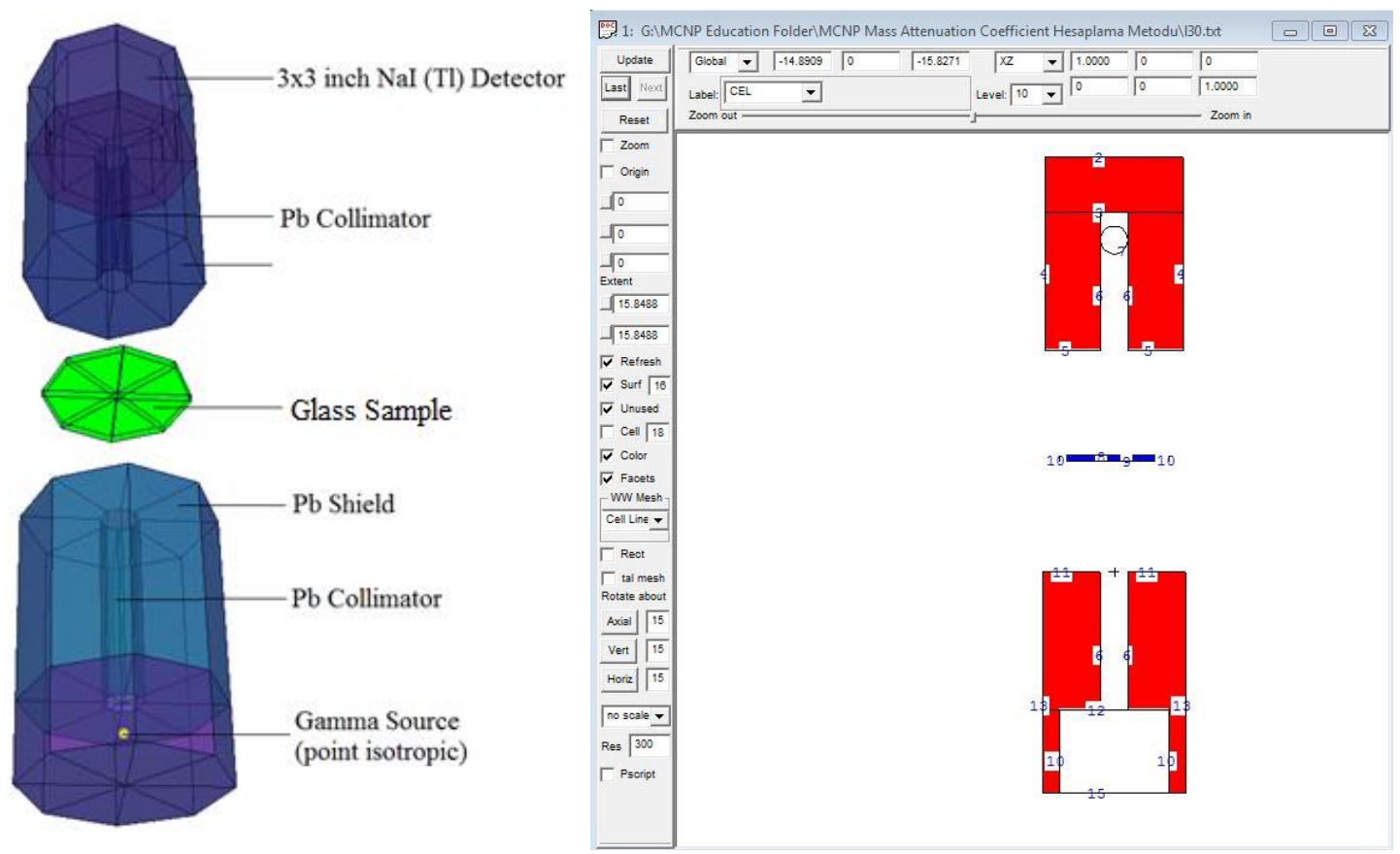

(a)
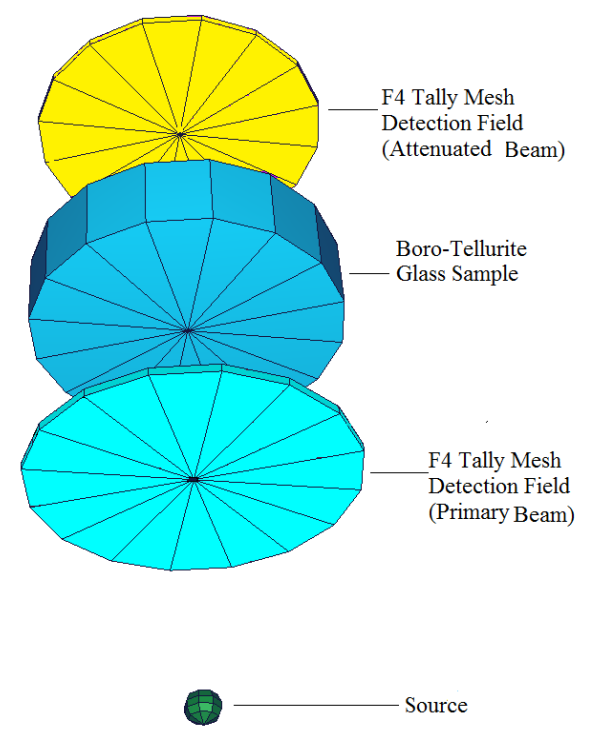

(b)

Figure 1. (a) MCNPX simulation setup obtained MCNPX Visual Editor (VE X_22S)for mass attenuation coefficients studies (b) MCNPX simulation setup obtained from MCNPX Visual Editor (VE X_22S) for photon transmission factor (TF) studies 


\subsection{Calculation method of shielding parameters}

As a high-energy photon passes through a substance of $\mathrm{x}$ thickness, its energy is absorbed and passes to the other side as its intensity is weakened exponentially. This reduction in radiation intensity is directly proportional to the $\mathrm{x}$-thickness and linear reduction coefficient of the absorber in reference to the Lambert-Beer law Eq. 1 [27]:

$$
I=I_{0} e^{-\mu x}
$$

where $I$ and $I_{0}$ are specifying the transmitted and primary intensity of gamma radiation, $\mu$ specify the linear attenuation coefficient and $\mathrm{x}$ is the thickness $(\mathrm{cm})$ of the shielding material. The linear attenuation coefficient is defined as the energy reduction fraction per unit thickness on the unit surface. Although the linear attenuation coefficient is only associated with thickness, this coefficient is attached to the energy of the photons and on the structure of the absorbent. The proportion of the linear attenuation coefficient to the material density is the reduction per unit mass on the unit time and is expressed as the coefficient of mass reduction.

The experimental mass attenuation coefficient $\mu / \rho$ of elements is expressed by:

$$
\mu_{m}=\frac{\mu}{\rho}
$$

The theoretical mass attenuation coefficient $\mu / \rho\left(\mathrm{cm}^{2} / \mathrm{g}\right)$ of lithium boro-tellurite glasses containing $\mathrm{ZnO}$ can be specified as Eq.3:

$$
\left(\frac{\mu}{\rho}\right)_{\text {glass }}=\sum_{i} w_{i}\left(\frac{\mu}{\rho}\right)_{i}
$$

where $w_{i}$ and $(\mu / \rho)_{i}$ are the fraction by weight and mass attenuation coefficient of the examined element in the sequence. To calculate the $(\mu / \rho)$ value of the examined glasses for a determined energy region XCOM and MCNP code should be used [28]. Additionally, the fraction by weight $w_{i}$ should be calculated by considering the number of element $n_{i}$ and atomic weight of the $i$ th element $A_{i}$ in a chemical compound as;

$$
w_{i}=\frac{n_{i} A_{i}}{\sum_{i} n_{i} A_{i}}
$$

The $\mu / \rho$ values of the examined glasses were examined by using the XCOM program based on the DOS-based compilation XCOM [28].

In nuclear physics, the possibility of radiation interacting with matter is considered a cross-section. The cross-section is considered to be the total cross-section of the whole material, rather than the interaction with a single atom. According to the experimental studies and the results obtained, the area of the total cross-section can be calculated. In line with these experimental data, the area of the total cross-section has been determined theoretically and formulated and approximate results have been obtained. Total cross-sections can be specified as the following equations[29];

$$
\begin{aligned}
& \sigma_{t, m}=\left(\frac{\mu}{\rho}\right) \frac{M}{N_{A}} \\
& \sigma_{t, a}=\frac{1}{N_{A}} \sum_{i} f_{i} A_{i}\left(\frac{\mu}{\rho}\right)_{i}=\frac{\sigma_{t, m}}{\sum_{i} n_{i}} \\
& \sigma_{t, e l}=\frac{1}{N_{A}} \sum_{i} \frac{f_{i} A_{i}}{Z_{i}}\left(\frac{\mu}{\rho}\right)_{i}=\frac{\sigma_{t, a}}{Z_{e f f}}
\end{aligned}
$$

$\sigma_{t, m}:$ Total molecular cross-section:

$\sigma_{t, a}:$ Total atomic cross-section

$\sigma_{t, e l}$ : Total electronic cross-section of the individual elements

$M=\sum_{i}\left(n_{i} A_{i}\right):$ Molecular weight

$\mathrm{N}_{\mathrm{A}}$ : Avogadro constant

$f_{i}$ : Fractional abundance of $i$ th element

$n_{i}$ : Number of element

$A_{i}$ : Atomic weight of the $\mathrm{i}$ th element of samples

$Z_{i}$ : Atomic number of the $i$ th element 
The effective atomic number $\left(Z_{e f f}\right)$ is a significant parameter for radiation absorptions of compounds, mixtures and alloys. Based on the variation of photon interaction cross section of the composite material element does not display the characteristic energy of the atomic number of the elements in all energies. Therefore, it has used the term atomic number for composite materials and it is stated that this value changes depending on the energy. The effective atomic number is theoretically the proportion of the total $\sigma_{t, a}$ (atomic cross-section) to the $\sigma_{t, e l}$ (total electronic cross-section) given in Eq. 8 [30].

$$
Z_{e f f}=\frac{\sigma_{t, a}}{\sigma_{t, e l}}
$$

The $Z_{\text {eff }}$ is a commonly used parameter for diagnosis and treatment, especially in nuclear medicine, for dose calculations and for radiation protection. The effective electron number, such as the electron density, is used for similar purposes [31]. The effective electron number indicates the number of electrons interacting with the substance in the unit mass.

$$
N_{e}=\frac{(\mu / \rho)}{\sigma_{t, e l}}=\frac{N_{A}}{M} Z_{e f f} \sum_{i} n_{i}=\frac{N_{A} Z_{e f f}}{\langle A\rangle}
$$

The average atomic mass in other words average atomic weight $\langle A\rangle[32,33]$ can be specified as;

$$
\langle A\rangle=\frac{M}{\sum_{i} n_{i}}
$$

Half-value layer (HVL) is the thickness of the material required to reduce the beam intensity to the half value of the principal intensity. The HVL shows that as the photon energy increases, energetic photons have the ability to permeate the sample. For the sample glasses, HVL can be examined by using the equation below,

$$
H V L=x_{1 / 2}=\frac{0.693}{\mu}
$$

The tenth value layer TVL is the thickness of material required to reduce the beam intensity to one-tenth of the initial intensity.

$$
T V L=x_{1 / 10}=\frac{\ln 10}{\mu}
$$

HVL, TVL and also (Mean free path) MFP are the most widely used theoretical parameters for radiation shielding efficiency for glass samples [34,35] and there is a correlation between them: $(1 H V L \cong 0,3 T V L)$. The average free path is the average distance the sample passes through before the single-particle interacts with the material and is calculated by the following equation.

$$
M F P=\frac{1}{\mu}
$$

The transmission factor of gamma-ray (TF), defined as (I/Io) can be determined using the attenuation coefficient and density of the material. In this case, certain thicknesses are selected for the shielding material or the thickness is selected to achieve a certain degree of attenuation at the source energies to use in the MCNP simulation program. Permeability based on material thickness and initial photon energy.

The probability of reaction by neutrons diminishes quickly as the neutron energy increases. However, scattering is very significant in a collision since it can pass on pretty much energy to the neutron. That's why it is of great importance to investigate the neutron blocking capacity of the shielding materials. The status of fast neutron attenuation is defined by a parameter named the "removal cross-section", unitized by $\left(\mathrm{cm}^{-1}\right)$. The effective removal cross-section, $\Sigma_{\mathrm{R}}\left(\mathrm{cm}^{2} / \mathrm{g}\right)$ is used to qualify the fast neutrons attenuation in glass samples and obtained by adding the individual mass removal cross-section of its components [33]:

$$
\Sigma_{R}=\sum_{i} W_{i}(\Sigma R / \rho)_{i}
$$

where $\mathrm{W}_{\mathrm{i}}$ is the partial density and equal to $W_{i}=w_{i} \rho_{s}$

$\Sigma R / \rho$ : Mass removal cross-section of the $\mathrm{i}$ th constituent $w_{i}$ : Weight fraction of the $\mathrm{i}$ th component 
$\rho_{s}$ : Density of the sample.

The exposure buildup factor (EBF) is a central parameter in determining the quality of radiation shielding features of glasses. To compute the EBF values we used G-P fitting method developed by Harima [36-38]. In the calculation processes, the $Z_{e q}$ values are derived by matching the $\left(\mu_{m}\right)_{\text {Compton }} /\left(\mu_{m}\right)_{\text {Total }}$ ratio of the specific energy with the appropriate ratio of the element with the help of the following equation.

$$
Z_{\text {eq }}=\frac{Z_{1}\left(\log R_{2}-\log R\right)+Z_{2}\left(\log R-\log R_{1}\right)}{\log R_{2}-\log R_{1}}
$$

where $Z_{1}$ and $Z_{2}$ indicates the atomic numbers of the samples.

At the later stage, using the ANSI / ANS-6.4.3 [39] standard reference database, the values of G-P fitting parameters in the 0.015-15 $\mathrm{MeV}$ energy region for the selected samples were then calculated. Finally, all these parameters obtained in the previous steps are utilized in order to calculate EBF values. Detailed information about calculations can be accessed from previous studies [40-44].

\section{Results and Discussion}

For studying the shielding features of glass samples having the compound $\mathrm{xZnO}(30-\mathrm{x}) \mathrm{Li}_{2} \mathrm{O}-10 \mathrm{TeO}_{2}-60 \mathrm{~B}_{2} \mathrm{O}_{3}(\mathrm{x}=0,5,10,15$ and $20 \mathrm{~mol} \%$ ), the mass attenuation coefficient (MAC) $\left(\mu_{m}=\mu / \rho\right)$ in the energy range from $0.02 \mathrm{MeV}$ to $20 \mathrm{MeV}$ were calculated applying $\mathrm{XCOM}$ program and the outcomes are drawn according to the photon energy (see Figure 2). As can be easily understood from Figure $2, \mu / \rho$ values are dropped rapidly to $0.06 \mathrm{MeV}$ as the photon energy increased since the photoelectric effect is dominant at low lying photon energy region and become constant after the energy range of $0.06 \mathrm{MeV}$ mid-level energies where the Compton effect is dominant. Additionally, it is easy to see that the reduction of the $\mathrm{Li}_{2} \mathrm{O}$ contribution and the increment of the $\mathrm{ZnO}$ contribution in sample glasses leads to the increment of $\mu / \rho$ values. In this case, it is clear that the ZL5 has the largest value of $\mu / \rho$ among the glass samples.

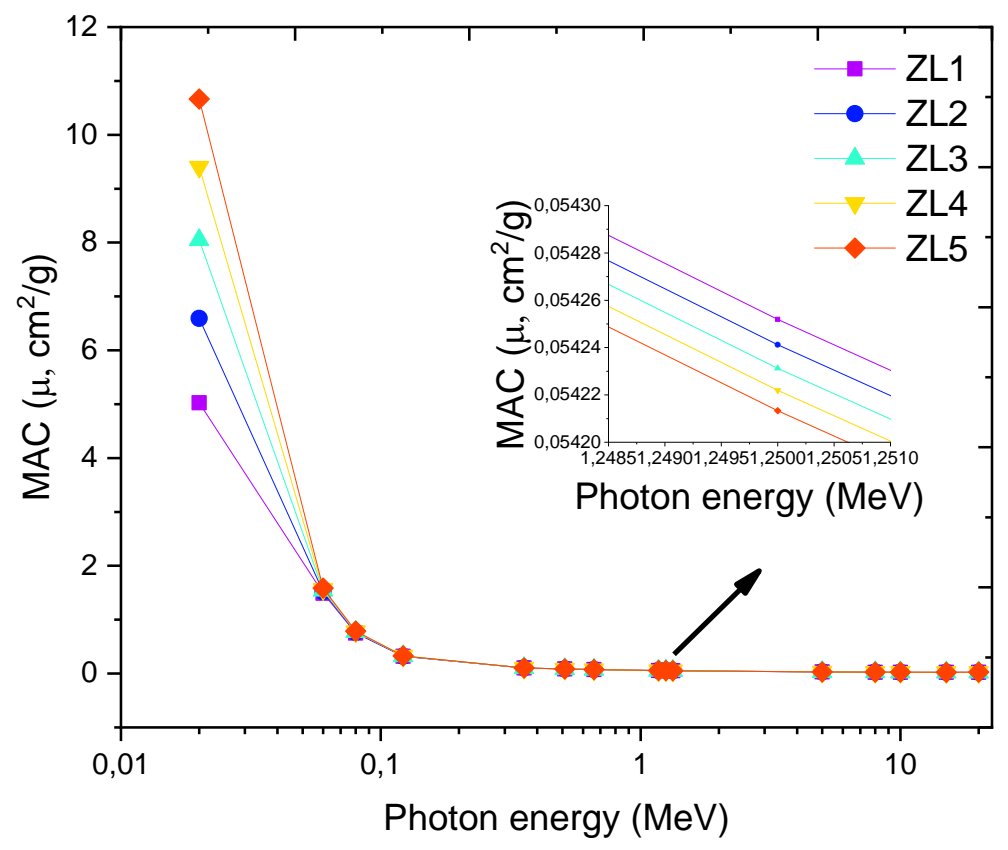

Figure 2. Mass attenuation coefficients ( $\mu / \rho)$ of the sample glasses with photon energy from 0.02 to $20 \mathrm{MeV}$.

The MCNPX simulation code and XCOM program were used to compare the simulation and theoretical results of the mass attenuation coefficients of the samples. The values compared between $0.02 \mathrm{MeV}-20 \mathrm{MeV}$ energy range are shown in Table 2. As is evident from Table 2, when gamma energies increase for glass samples it was determined that the mass attenuation coefficients go down and run up with the rise of $\mathrm{ZnO}$ contribution. This demonstrates that an increase in photon interactions in low photon energies with the increase of $\mathrm{ZnO}$ contribution in samples varies by $\sim \mathrm{Z}^{4} / \mathrm{E}^{3}$. Table 2 also shows that the results obtained by the XCOM program and MCNPX code are consistent with each other. 
Table 2. Mass Attenuation Coefficients $\left(\mu_{m}\right)$ for the Glass Samples Estimated by WinXCom Program

\begin{tabular}{|c|c|c|c|c|c|c|c|c|c|c|}
\hline \multirow{2}{*}{$\begin{array}{l}\text { Energy } \\
(\mathrm{MeV})\end{array}$} & \multicolumn{2}{|c|}{ ZL1 } & \multicolumn{2}{|c|}{ ZL2 } & \multicolumn{2}{|c|}{ ZL3 } & \multicolumn{2}{|c|}{ ZL4 } & \multicolumn{2}{|l|}{ ZL5 } \\
\hline & MCNPX & XCOM & MCNPX & ХCOM & MCNPX & ХСОМ & MCNPX & ХСОМ & MCNPX & ХСОМ \\
\hline 0.020 & 5,156985 & 5.026482 & 6,612855 & 6.593171 & 8,125587 & 8.047543 & 9,546630 & 9.401257 & 11,253304 & 10.664414 \\
\hline 0.060 & 1,515247 & 1.491934 & 1,523680 & 1.518109 & 1,552310 & 1.542408 & 1,572561 & 1.565025 & 1,596341 & 1.586129 \\
\hline 0.080 & 0,763354 & 0.752418 & 0,772564 & 0.762566 & 0,785130 & 0.771985 & 0,795564 & 0.780757 & 0,800504 & 0.788939 \\
\hline 0.122 & 0,325504 & 0.319874 & 0,332007 & 0.322427 & 0,338521 & 0.324798 & 0,342235 & 0.327005 & 0,345216 & 0.329064 \\
\hline 0.356 & 0,105054 & 0.104144 & 0,105214 & 0.104229 & 0,107877 & 0.104307 & 0,110042 & 0.104381 & 0,112581 & 0.104449 \\
\hline 0.511 & 0,087622 & 0.085436 & 0,087714 & 0.085455 & 0,088021 & 0.085473 & 0,088521 & 0.085490 & 0,088624 & 0.085505 \\
\hline 0.662 & 0,075320 & 0.074942 & 0,075412 & 0.074943 & 0,075996 & 0.074943 & 0,076120 & 0.074944 & 0,076216 & 0.074945 \\
\hline 1.173 & 0,057004 & 0.056076 & 0,057116 & 0.056063 & 0,057598 & 0.056052 & 0,057419 & 0.056041 & 0,057516 & 0.056031 \\
\hline 1.250 & 0,054627 & 0.054252 & 0,054712 & 0.054241 & 0,054991 & 0.054231 & 0,055114 & 0.054222 & 0,055201 & 0.054213 \\
\hline 1.330 & 0,052722 & 0.052530 & 0,052789 & 0.052522 & 0,052901 & 0.052514 & 0,052991 & 0.052507 & 0,052824 & 0.052500 \\
\hline 5.000 & 0,028831 & 0.028228 & 0,028851 & 0.028475 & 0,028755 & 0.028704 & 0,028854 & 0.028917 & 0,029459 & 0.029115 \\
\hline 8.000 & 0,025335 & 0.024392 & 0,025651 & 0.024793 & 0,025810 & 0.025166 & 0,026115 & 0.025512 & 0,026710 & 0.025836 \\
\hline 10.000 & 0,023530 & 0.023279 & 0,023945 & 0.023759 & 0,024511 & 0.024205 & 0,024901 & 0.024619 & 0,025698 & 0.025006 \\
\hline 15.000 & 0,022846 & 0.022192 & 0,023004 & 0.022815 & 0,023759 & 0.023394 & 0,024511 & 0.023933 & 0,025204 & 0.024436 \\
\hline 20.000 & 0,022914 & 0.022003 & 0,022988 & 0.022730 & 0,023810 & 0.023405 & 0,024357 & 0.024033 & 0,025881 & 0.024620 \\
\hline
\end{tabular}

The HVL, TVL and MFP values of the sample glasses are shown in Figures 3 and 4 (a, b). These values are very small in the low energy region of photon and these values are reduced by the increasing concentration of ZnO. HVL and TVL values were almost constant up to $0.1 \mathrm{MeV}$ energy for all glass samples, after which a quick increase occurred in these values and reached the peak value of $15 \mathrm{MeV}$. The differences in these values for existing glass samples can be specified as the domination of varied photon interaction types in varied energy zone. In addition, these values decrease with the increasing densities of the subject glass samples. It is important to note that the low MFP, HVL and TVL values are necessary for a preferable gamma ray protection material since the possibility of photon interaction by the material is higher. According to this result, when we compare glass samples, it is understood that the ZL5 glass sample with minimum HVL, TVL, MFP and maximum density and mass attenuation coefficient has the best protection features among the glass samples.

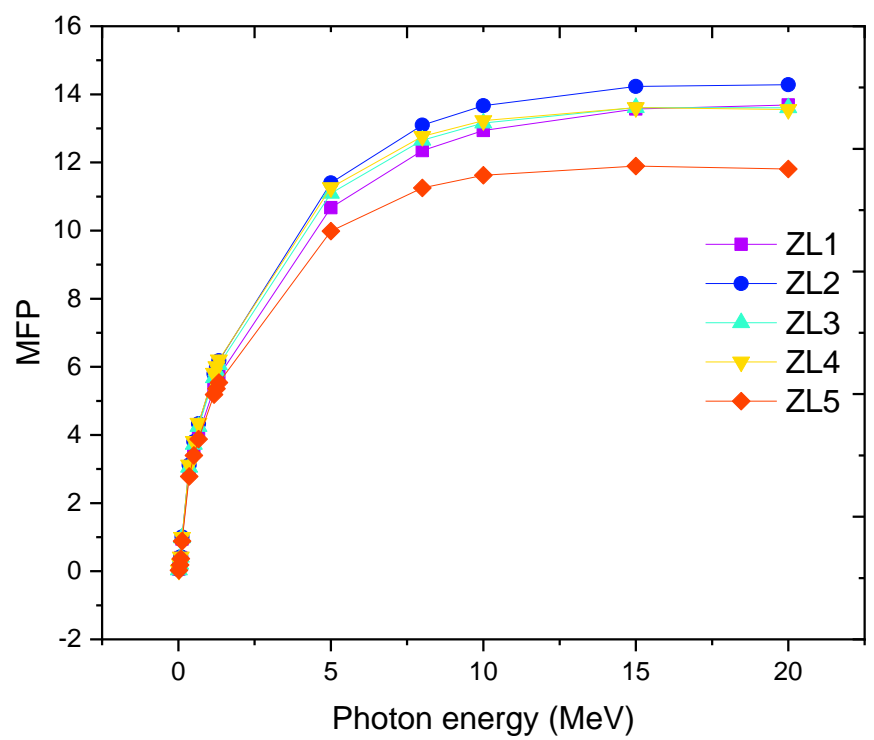

Figure 3. Mean free path (MFP) of investigated glass samples. 


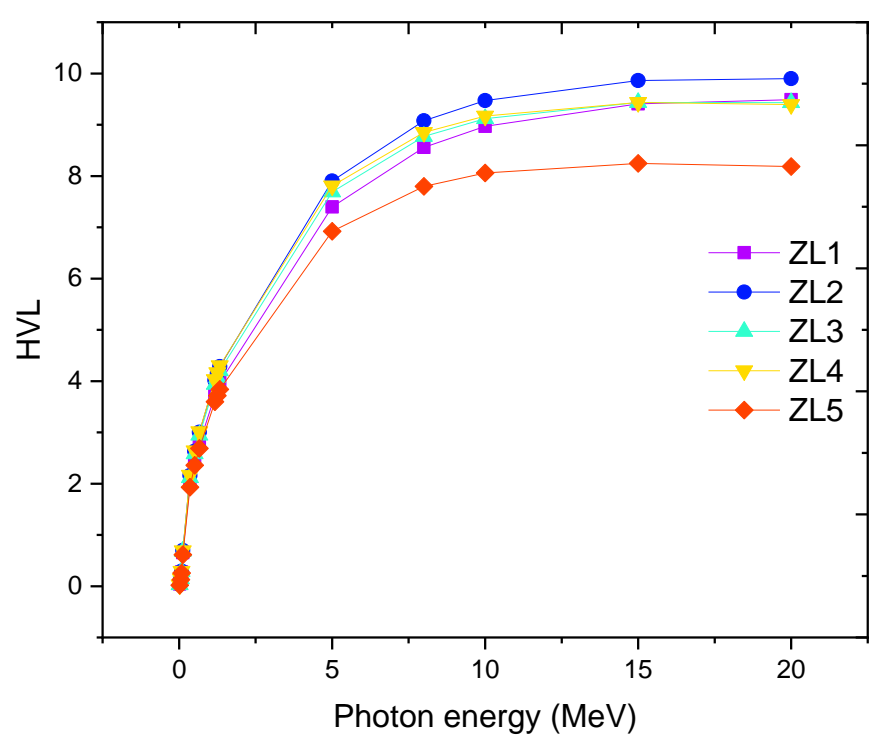

a)

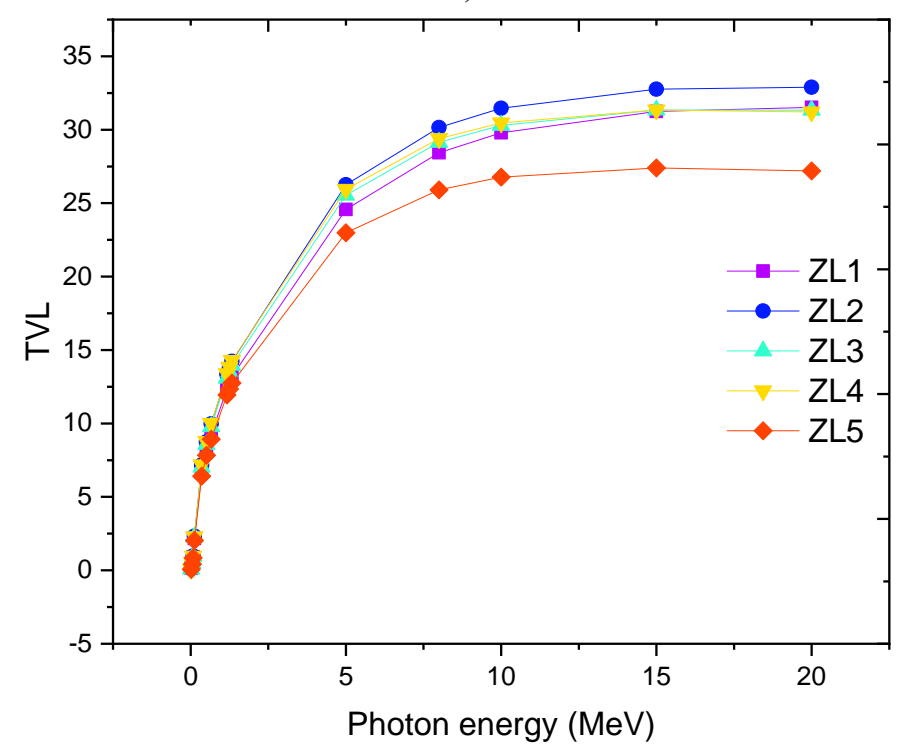

b)

Figure 4. a)Half (HVL) and b) tenth value layer (TVL) of investigated glass samples.

Figure 5 indicates the changes in the effective atomic number $\left(\mathrm{Z}_{\text {eff }}\right)$ of the $\mathrm{ZnO}$ doped lithium boro-tellurite glasses according to the gamma-ray energies in the region of $0.02 \mathrm{MeV}$ to $20 \mathrm{MeV}$. As shown in Figure 5, a quick jump occurred at the $0.06 \mathrm{MeV}$ energy range with the increment of the Zn contribution in glass structures except for the glass sample ZL1. The reason is photoelectric cross-section dependence on the $Z^{4-5}$. Moreover, a remarkable decrease of $Z_{\text {eff }}$ values in the region of $0.04 \mathrm{MeV}-0.1 \mathrm{MeV}$ takes place with the increment of the photon energy for the glass samples. When the photon energy rice further, the $Z_{\text {eff }}$ becoming virtually stand-alone from photon energy. The prevailing of the Compton scattering case can be one of the main reasons. When the value is higher than $2.0 \mathrm{MeV}$, the $Z_{\text {eff }}$ demonstrates a slow increment and this indicates that pair production is dominant. As can be understood from Figure 5, the $Z_{\text {eff }}$ is highest for sample ZL5. The alteration of electron density for examined sample glasses with photon energy indicates the same action as in Zeff, can be seen in Figure 6. 


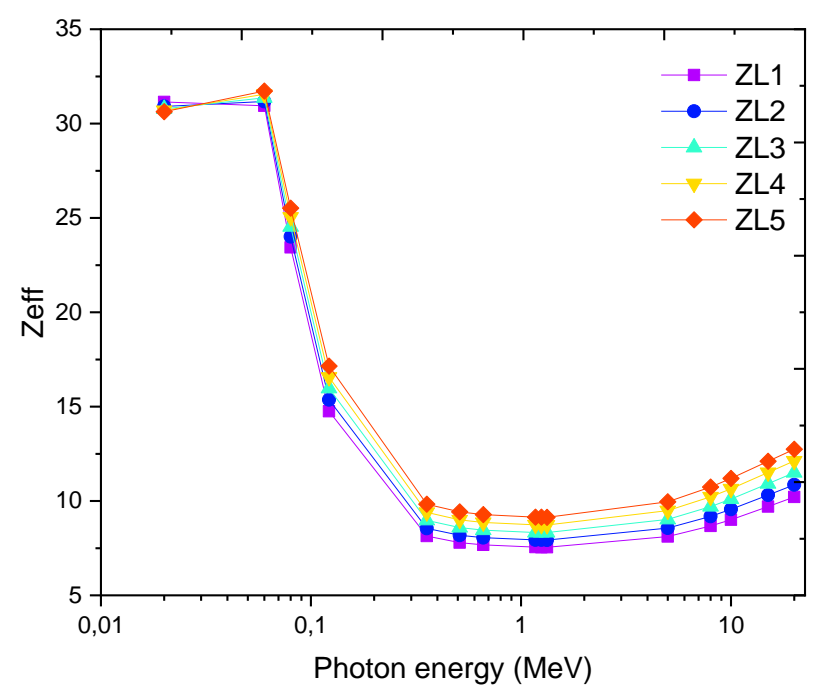

Figure 5. Effective atomic numbers $\left(Z_{\text {eff }}\right)$ of the glass samples with photon energy.

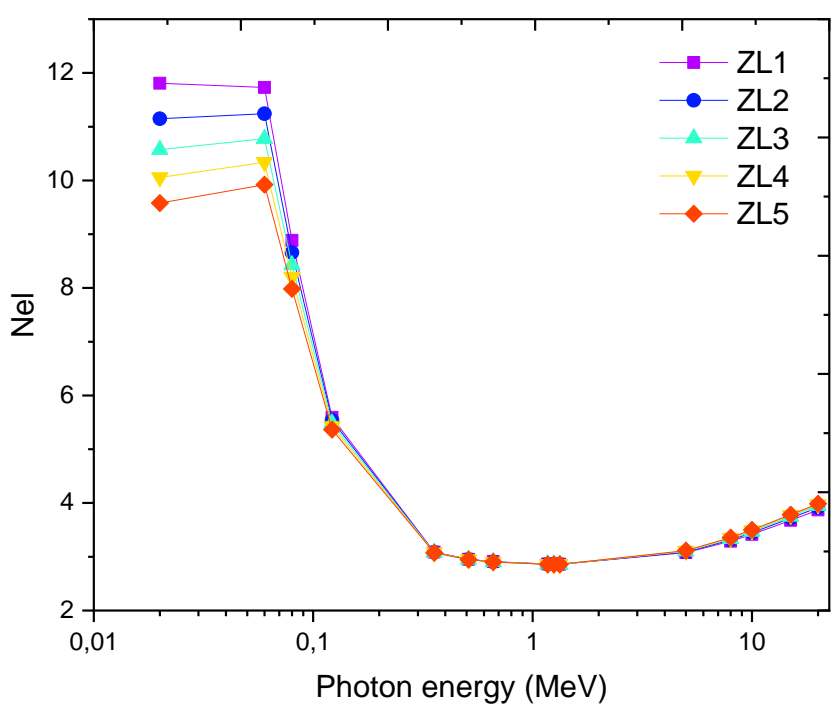

Figure 6. Effective electron density $\left(N_{e l}\right)$ of the glass samples with photon energy

The calculated gamma-ray transmission factors (TFs) depending on thickness (x) are shown in Figure 7, calculated by the MCNPX program for specific energies. As one can see from the figure the TF values drop rapidly with the increasement of mass thickness and better attenuation (minimum values of TFs) is achieved in high energy regions. The difference between the TF values of the samples changes from $0.87 \%$ to $0.11 \%$. ZL5 is the best absorbent between the glass samples for both neutron and gamma radiation. Figure 7 shows that the transmission factor for the glass samples aligns considering the following order: ZL1>ZL2>ZL3 $>$ ZL4 $>$ ZL5. Effective removal cross-section $\left(\Sigma_{\mathrm{R}}\right)$, Mass removal cross-section of the ith compound $(\Sigma R / \rho)$, the weight fraction of the ith component and partial densities of the samples are listed in Table 3 for examined glass samples. According to Table 3, a slight increase in $\Sigma_{R}$ values was determined as the amount of $\mathrm{Zn}$ increased in glass samples. On the other hand, there was no significant difference between the $\Sigma_{\mathrm{R}}$ values of the examined glass samples. Changes in values are owing to the density differences of the glass samples, so it is educed that density plays an important role in fast neutron protection. 


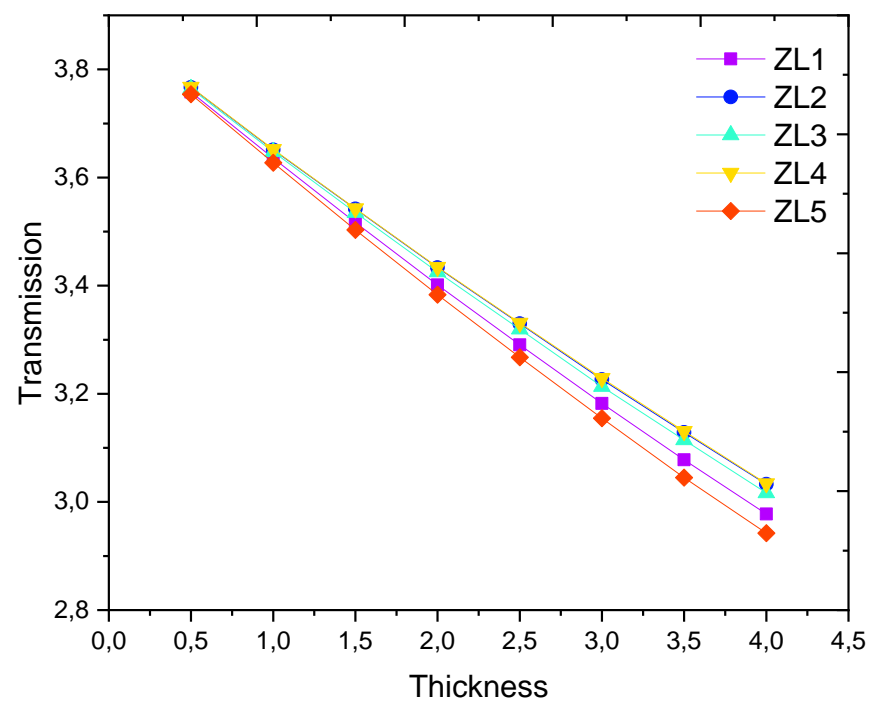

Figure 7. Transmission factors (TFs) as a function of shielding thickness.

Table 3. Effective removal cross sections for the glass samples

\begin{tabular}{|c|c|c|c|c|c|c|c|}
\hline & & \multicolumn{3}{|c|}{ ZL1 $\left(\right.$ density $\left.=3.32 \mathrm{~g} / \mathrm{cm}^{3}\right)$} & \multicolumn{3}{|c|}{ ZL2 $\left(\right.$ density $\left.=3.08 \mathrm{~g} / \mathrm{cm}^{3}\right)$} \\
\hline Element & $\underset{\left(\mathbf{c m}^{2} / \mathbf{g}\right)}{\sum \mathbf{R} / \mathbf{p}}$ & $\begin{array}{c}\text { Fraction } \\
\text { by } \\
\text { weight } \\
(\%)\end{array}$ & $\begin{array}{l}\text { Partial } \\
\text { Density } \\
\left(\mathrm{g} \mathrm{cm}^{-3}\right)\end{array}$ & $\sum \mathbf{R}\left(\mathbf{c m}^{-1}\right)$ & $\begin{array}{c}\text { Fraction } \\
\text { by } \\
\text { weight } \\
(\%)\end{array}$ & $\begin{array}{l}\text { Partial } \\
\text { Density } \\
\left(\mathrm{g} \mathrm{cm}^{-3}\right)\end{array}$ & $\sum \mathbf{R}\left(\mathbf{c m}^{-1}\right)$ \\
\hline B & 0.0575 & 0.194511 & 0.645777 & 0.037132 & 0.187280 & 0.576821 & 0.033167 \\
\hline Zn & 0.0183 & 0.000000 & 0.000000 & 0.000000 & 0.047198 & 0.145370 & 0.002660 \\
\hline $\mathbf{O}$ & 0.0405 & 0.551733 & 1.831754 & 0.074186 & 0.531221 & 1.636160 & 0.066264 \\
\hline Te & 0.0134 & 0.191315 & 0.635165 & 0.008511 & 0.184202 & 0.567342 & 0.007602 \\
\hline $\mathbf{L i}$ & 0.0840 & 0.062441 & 0.207305 & 0.017414 & 0.050100 & 0.154307 & 0.012962 \\
\hline \multirow[t]{2}{*}{ TOTAL } & & & & 0.137243 & & & 0.122656 \\
\hline & & \multicolumn{3}{|c|}{ ZL4 $\left(\right.$ density $\left.=3.07 \mathrm{~g} / \mathrm{cm}^{3}\right)$} & \multicolumn{3}{|c|}{ ZL5 $\left(\right.$ density $\left.=3.44 \mathrm{~g} / \mathrm{cm}^{3}\right)$} \\
\hline Element & $\underset{\left(\mathbf{c m}^{2} / \mathbf{g}\right)}{\sum \mathbf{R} / \mathbf{p}}$ & $\begin{array}{c}\text { Fraction } \\
\text { by } \\
\text { weight } \\
(\%)\end{array}$ & $\begin{array}{l}\text { Partial } \\
\text { Density } \\
\left(\mathrm{g} \mathrm{cm}^{-3}\right)\end{array}$ & $\sum \mathbf{R}\left(\mathbf{c m}^{-1}\right)$ & $\begin{array}{c}\text { Fraction } \\
\text { by } \\
\text { weight } \\
(\%)\end{array}$ & $\begin{array}{l}\text { Partial } \\
\text { Density } \\
\left(\mathrm{g} \mathrm{cm}^{-3}\right)\end{array}$ & $\sum \mathbf{R}\left(\mathbf{c m}^{-1}\right)$ \\
\hline $\mathbf{B}$ & 0.0575 & 0.174318 & 0.535156 & 0.030771 & 0.168487 & 0.579597 & 0.033327 \\
\hline $\mathbf{Z n}$ & 0.0183 & 0.131795 & 0.404609 & 0.007404 & 0.169849 & 0.584279 & 0.010692 \\
\hline $\mathbf{O}$ & 0.0405 & 0.494455 & 1.517976 & 0.061478 & 0.477916 & 1.644033 & 0.066583 \\
\hline Te & 0.0134 & 0.171453 & 0.526361 & 0.007053 & 0.165719 & 0.570072 & 0.007639 \\
\hline $\mathbf{L i}$ & 0.0840 & 0.027979 & 0.085897 & 0.007215 & 0.018029 & 0.062020 & 0.005210 \\
\hline TOTAL & & & & 0.113922 & & & 0.123451 \\
\hline
\end{tabular}

The $\Sigma_{R}$ value of Sample ZL1 has been shown to have a maximum value between the other glass samples (Figure 8). This can be explained by its higher $\mathrm{Li}_{2} \mathrm{O}$ content among the glass samples since Li's effective removal cross-section is bigger than $\mathrm{Zn}$. In this study, we have calculated the EBF values of the selected glasses in $0.015-15 \mathrm{MeV}$ up to $15 \mathrm{MFP}$ by utilizing the G-P fitting approach. The EBF values are plotted in Figure 9. 


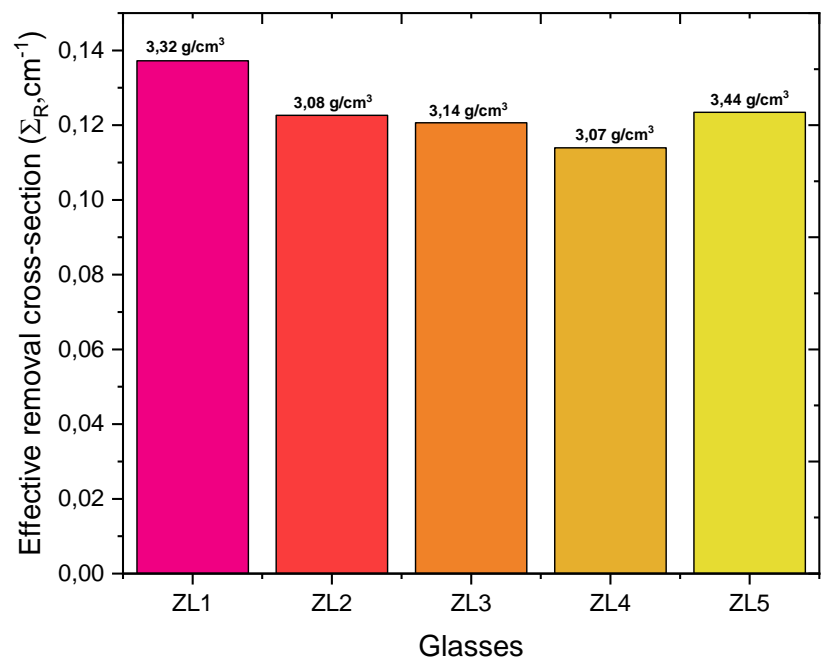

Figure 8. Effective removal cross-section values of the glasses with density
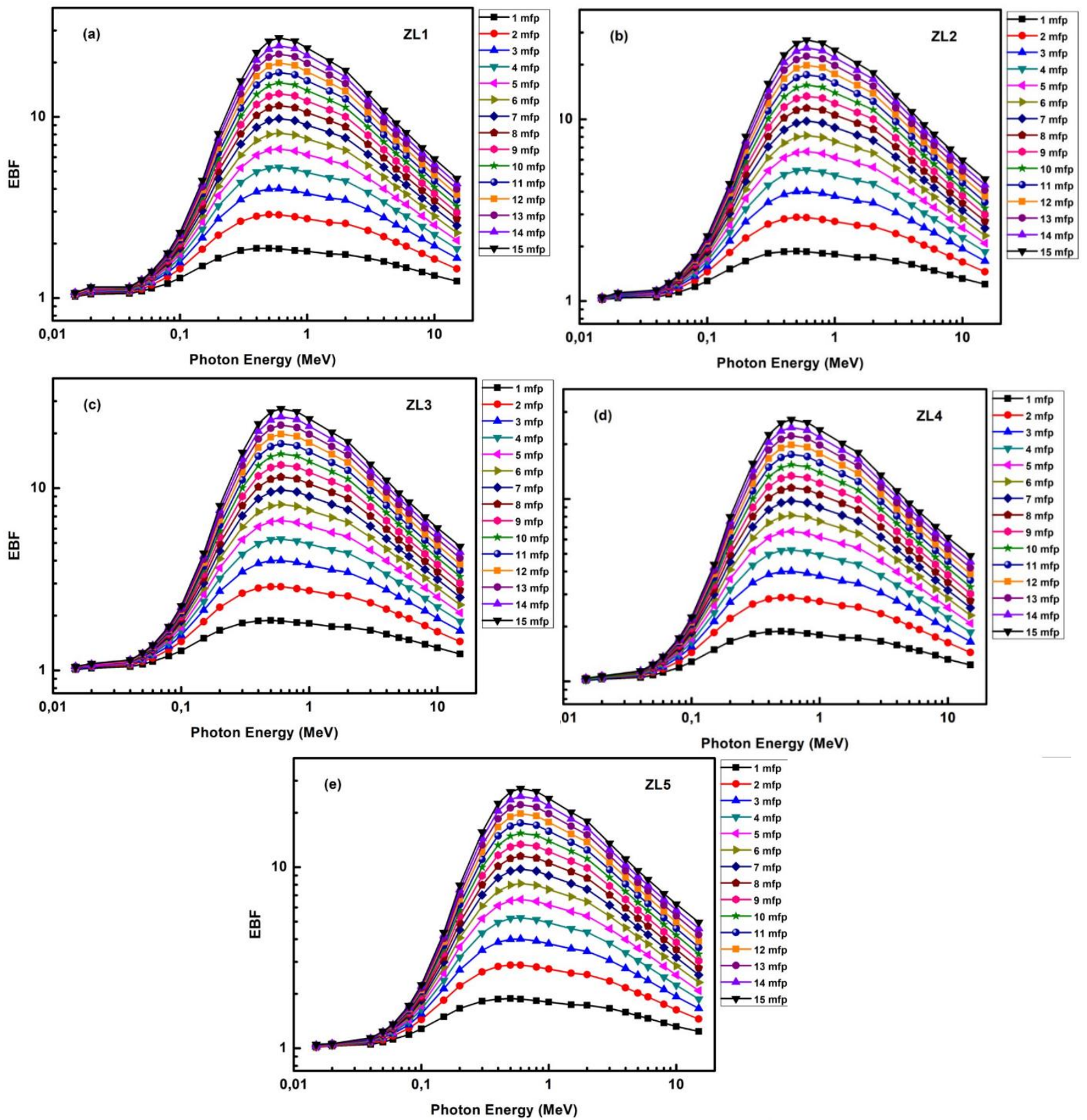

Figure 9. (a-e) The exposure buildup factors in the energy region 0.015-15 MeV at the 1-15 mfp for glass samples 
The figure shows us that EBF values remain very low at first, and start rising fast as the energy level rises [40,41]. That indicates an inverse relationship between energy and EBF. Yet, at $0.6 \mathrm{MeV}$, the EBF values extended to its maximum and after that peak, it keeps decreasing even if the energy level rises. That is simply because we have different processes derived from the energy and matter interaction at different (low, mid and high) levels. Photoelectric effect grows into dominance at the low energy levels yielding an inverse effect with $\mathrm{E}^{3.5}$. The sample of glasses absorbs the maximum level of low energy photons as the build-up for the photons are constricted at this energy region. Compton scattering is the process that becomes a dominant incident at the intermediate energies yielding high EBF. The high EBF is because of the multiple scattering processes rather than MFP. Pair production becomes dominant when it comes to high energies yielding lower EBF as the photon energy rises [42,44]. With the highest $Z_{\text {eq }}$ value, ZL5 yields the minimum EBF values (Figure 10).

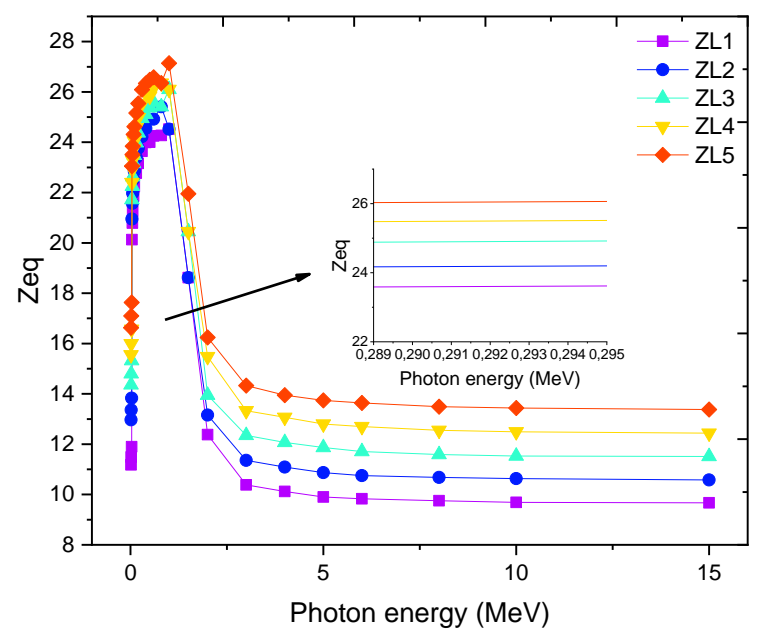

Figure 10. Equivalent atomic numbers of the glass samples with photon energy

\section{Conclusions}

In summary, the modifier role of $\mathrm{ZnO}$ in for lithium boro-tellurite glass samples was determined by calculating mass attenuation coefficient $(\mu / \rho)$ by XCOM software and MCNPX code. Comparing the values of XCOM and MCNPX, it can be easily seen that $\mu / \rho$ values are in compliance with each other. In addition to the mass attenuation coefficient, $Z_{\text {eff }}, N_{\text {el }}, H V L, T V L, M F P, T F, \Sigma_{R}, Z e q, E B F$ shielding parameters were also calculated. According to the results of this study, $\mu / \rho$ and Zeff values are go up with increasing $\mathrm{ZnO}$

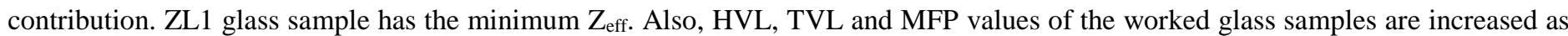
the photon energy goes up and decreased as the amount of ZnO additive increases. Sample ZL5 has the smallest value among the other glass samples. $\Sigma_{R}$ values together with transmission factors were also examined for the glass samples. Sample ZL5 has the smallest TF values, whereas Sample ZL1 has the biggest $\Sigma_{R}$ values among the glass samples. Moreover, among the selected glasses (i.e. ZL1), the one with the lowest $Z_{\text {eq }}$ has the maximum EBF, as the one (i.e. ZL5) with the highest $Z_{\text {eq }}$ provide the minimum EBF. In this sense, ZL5is better than ZL1 as a radiation attenuator in terms of EBF values. The hypothesis of this study is to observe an improvement in the radiation attenuation properties of glass samples with increasing $\mathrm{ZnO}$ ratio. The results of this study prove the accuracy of the proposed hypothesis. The amount of increase in the $\mathrm{ZnO}$ additive is not very high in glass samples. Therefore, the presented results of the samples can be shed light on radiation physics medical applications and shielding research for future studies.

\section{References}

1. R. A. H. El-Mallawany, Tellurite Glasses Handbook Physical Properties and Data. Boca Raton: CRC Press, (2002).

2. P. Kostka, J. Zavadil, J. Pedlikoval, M. Poulain, Preparation and Optical Characterization of PbCl2-Sb2O3-TeO2 Glasses Doped with Rare Earth Elements, Phys. Status Solidi A, 208, 821-1826, (2011).

3. I. M. Ashraf, S. Almoeed, E. Yousef, Enhanced thermal stability and optical properties in $\mathrm{Tm}^{3+} / \mathrm{Dy}^{3+}$ ions codoped TNbZ glasses. Optik, 131, 221-230, (2017).

4. M. Çelikbilek, A. E. Ersundu E. O. Zayim, and S. Aydın, Thermochromic behavior of tellurite glasses. Journal of Alloys and Compounds, 637, 162-170, (2015).

5. R. A. H. El-Mallawany, Tellurite Glasses Handbook Physical Properties and Data. Boca Raton: CRC Press, (2002).

6. S. Terny, M. A. De la Rubia, J. De Frutos, M. A. Frecheroa, A new transition metal-tellurite glass family: Electrical and structural properties. Journal of Non-Crystalline Solids, 433, 68-74, (2016). 
7. P. Gayathri Pavani, K. Sadhana, V. Chandra Mouli, Optical, physical and structural studies of boro-zinc tellurite glasses, Physica B 406, 1242-1247, doi: 10.1016/j.physb.2011.01.006 (2011).

8. S. L. Meena, B. Bhatia, Polarizability and Optical Basicity of Er3+ Ions Doped Zinc Lithium Bismuth Borate Glasses J. Pure Appl. Ind. Phys. 6 (10), 75-83, (2016).

9. S. Thirumaran, K. Sathish, Spectroscopic investigations on structural characterization of borate glass specimen doped with transition metal ions, Res. J. Chem. Environ. 18 (10), 77-82, (2015).

10. K.A. Matori, M. Hafiz, M. Zaid, H.J. Quah, S. Hj, A. Aziz, Studying the Effect of ZnO on Physical and Elastic Properties of (ZnO)x(P2O5)1-x Glasses Using Nondestructive Ultrasonic Method, Adv. Mater. Sci. Eng., 596361, , https://doi.org/10.1155/2015/596361, (2015).

11. D. Dutta, M. P. F. Graca, M. A. Valente and S. K. Mendiratta, Structural characteristics and dielectric response of some zinc tellurite glasses and glass ceramics, Solid State Ionics 230 66, (2013).

12. E. A. Mohamed, F. Ahmad and K. A. Aly, Effect of lithium addition on thermal and optical properties of zinc-tellurite glass, J. Alloys Compd. 538 230, doi.org/10.1016/j.jallcom.2012.05.044. (2012).

13. Y. B. Saddeek, H. A. Afifi and N. S. A. El-Aal, Interpretation of mechanical properties and structure of TeO2-Li2O-B2O3 glasses, Phys. B 398 1, doi.:10.1016/j.physb.2007.04.011 (2007).

14. P. Mosner, K. Vosejpkova, L. Koudelka, L. Montagne and B. Revel, Structure and properties of $\mathrm{ZnO}_{-}-\mathrm{B}_{2} \mathrm{O}_{3}-\mathrm{P}_{2} \mathrm{O}_{5}-\mathrm{TeO}_{2}$ glasses, Mater. Chem. Phys. 124 732, doi:10.1016/j.matchemphys.2010.07.048. (2010).

15. Ghada El. Falaky, W. Guirguis Osiris, Effect of zinc on the physical properties of borate glasses, J. Non-Cryst. Solids 358,17461752, DOI: 10.1016/j.jnoncrysol.2012.05.009.(2012).

16. Y.B. Saddeek, K.A. Aly, K.S. Shaaban, Atif Mossad Ali, Moteb M. Alqhtani, Ali M. Alshehri, M.A. Sayed, E.A. Abdel Wahab, Physical properties of $\mathrm{B}_{2} \mathrm{O}_{3}-\mathrm{TeO}_{2}-\mathrm{Bi}_{2} \mathrm{O}_{3}$ glass system, J. Non-Cryst. Solids 498, 82-88, (2018).

17. Y. Saddeek, H. Mohamed, M. Azzoz, Structural study of some divalent aluminoborate glasses using ultrasonic and positron annihilation techniques, Phys. Status Solidi A 201 (9), 2053, (2004).

18. G. Lakshminarayana, S.O. Baki, M.I. Sayyed, M.G. Dong, A. Lira, A.S.M. Noor, I.V. Kityk, M.A. Mahdi, Vibrational, thermal features, and photon attenuation coefficients evaluation for TeO2-B2O3-BaO-ZnO-Na2O-Er2O3-Pr6O11 glasses as gamma-rays shielding materials, J. Non-Cryst. Solids 481, 568-578, (2018).

19. N. Elkhoshkhany, Samir Y. Marzouk, Nourhan Moataz, Sherif H. Kandil, Structural and optical properties of TeO2-Li2O-ZnONb2O5-Er2O3 glass system, J. Non- Cryst. Solids 500, 289-301, (2018).

20. S. Rani, N. Ahlawat, R. Parmar, S. Dhankhar, R.S. Kundu, Role of lithium ions on the physical, structural and optical properties of zinc boro tellurite glasses, Indian J. Phy. 92 (7), 901-909, (2018).

21. M.G. Donga, M.I. Sayyedb, G. Lakshminarayanac, M. Çelikbilek Ersundud, A.E. Ersundud, Priyanka Nayare, M.A. Mahdic, Investigation of gamma radiation shielding properties of lithium zinc bismuth borate glasses using XCOM program and MCNP5 code, Journal of Non-Crystalline Solids, 468, 12-16, (2017).

22. P. Naresh, B. Kavitha, Hajeebaba K. Inamdar, D. Sreenivasu, N. Narsimlu, Ch. Srinivas, Vasant Sathe, K. Siva Kumar, Modifier role of $\mathrm{ZnO}$ on the structural and transport properties of lithium boro tellurite glasses, Journal of Non-Crystalline Solids 514, 3545, (2019).

23. Team, X.-5 M.C.: MCNP, A General Monte Carlo N-Particle Transport Code, Version 5 Volume I: Overview and Theory. (2003) p.

24. H.O. Tekin., MCNP-X Monte Carlo Code Application for Mass Attenuation Coefficients of Concrete at Different Energies by Modeling $3 \times 3$ inch NaI(Tl) Detector and Comparison with XCOM and Monte Carlo Data, Science and Technology of Nuclear Installations, Article ID 6547318, 7 pages. doi: https://doi.org/10.1155/2016/6547318, (2016)

25. M. J. Berger, J. H. Hubbell, S. M. Seltzer, J. Chang, J. S. Coursey, R. Sukumar, D. S. Zucker, K. Olsen, XCOM: Photon Cross Sections Database, NIST Standard Reference Database 8 (XGAM).

26. O. Agar, M.I. Sayyed, F. Akman, H.O. Tekin, M.R. Kacal. An extensive investigation on gamma ray shielding features of Pd/Agbased alloys. Nuclear Engineering and Technology, 51(3), 853-859. doi.:10.1016/j.net.2018.12.014. (2018).

27. M.I. Sayyed, Bismuth modified shielding properties of zinc boro-tellurite glasses, J. Alloy. Compd. 688, 111-117. doi:/10.1016/j.jallcom.2016.07.153.(2016).

28. F. Akman, M. I. Sayyed, M. R. Kaçal, H. O. Tekin, Investigation of photon shielding performances of some selected alloys by experimental data, theoretical and MCNPX code in the energy range of $81 \mathrm{keV}-1333 \mathrm{keV}$. J. Alloys Compd. DOI: 10.1016/j.jallcom.2018.09.177. (2019).

29. H. O. Tekin, O. Kilicoglu, E. Kavaz, E. E. Altunsoy, M. Almatari, O. Agar, M. I. Sayyed, The investigation of gamma-ray and neutron shielding parameters of Na2O-CaO-P2O5-SiO2 bioactive glasses using MCNPX code. Results Phys. 12, 1797, 1797-1804 doi.:10.1016/j.rinp.2019.02.017. (2019).

30. F. Akman, I. H. Geçibesler, I. Demirkol, A. Çetin, Determination of effective atomic numbers and electron densities for some synthesized triazoles from the measured total mass attenuation coefficients at different energies. Can. J. Phys. 97(1): 86-92, doi.:10.1139/cjp-2017-0923 (2018).

31. G. J. Hine, The effective atomic numbers of materials for various gamma ray interactions, Phys. Rev. 1952, 85, 725.

32. F. Akman, R. Durak, M. F. Turhan, M. R. Kaçal, Studies on effective atomic numbers, electron densities from mass attenuation coefficients near the K edge in some samarium compounds. Appl. Radiat. Isot. doi.:10.1016/j.apradiso.2015.04.001. (2015).

33. H. O. Tekin, E. E. Altunsoy, E. Kavaz, M. I. Sayyed, O. Agar, M. Kamislioglu, Photon and neutron shielding performance of boron phosphate glasses for diagnostic radiology facilities. Results Phys. 12, 1457, doi.:/10.1016/j.rinp.2019.01.060. (2019).

34. S. R.Manohara, S.M. Hanagodimath, and L. Gerward, Energy dependence of effective atomic numbers for photon energy absorption and photon interaction: studies of some biological molecules in the energy range $1 \mathrm{keV}-20 \mathrm{MeV}$, Medical Physics, vol. 35, no. 1, 
pp. 388-402, DOI: 10.1118/1.2815936. (2008).

35. J. F. Ziegler, M. Ziegler, J. Biersack, SRIM - The stopping and range of ions in matter (2010), Nuclear Instruments and Methods in Physics Research Section B 268 (11-12), 1818-1823. doi:10.1016/j.nimb.2010.02.091. (2010).

36. Y. Harima, An approximation of gamma-ray buildup factors by modified geometrical progression, Nucl. Sci. Eng., 83, pp. 299309, doi.org/10.13182/NSE83-A18222 (1983).

37. M. I. Sayyed, M. G. Dong, H. O. Tekin, G. Lakshminarayana, M. A. Mahdi, Comparative investigations of gamma and neutron radiation shielding parameters for different borate and tellurite glass systems using WinXCom program and MCNPX code, Mater. Chem. Phys., 215, pp. 183-202, doi.org/10.1016/j.matchemphys.2018.04.106 (2018).

38. S. R. Manohara, S. M. Hanagodimath, L. Gerward, Energy absorption buildup factors for thermoluminescent dosimetric materials and their tissue equivalence, Radiat. Phys. Chem., 79, pp. 575-582, doi.org/10.1016/j.radphyschem.2010.01.002 (2010).

39. ANSI/ANS-6.4.3, Gamma Ray Attenuation Coefficient and Buildup Factors for Engineering Materials, Am. Nucl. Soc. La Grange (1991).

40. O. Kilicoglu, Characterization of copper oxide and cobalt oxide substituted bioactive glasses for gamma and neutron shielding applications, Ceramics International, 45 (17), 23619-23631, doi.org/10.1016/j.ceramint.2019.08.073. (2019).

41. S.A. Issa, H.O. Tekin, R. Elsaman, O. Kilicoglu, Y.B. Saddeek, M.I. Sayyed, Radiation shielding and mechanical properties of $\mathrm{Al}_{2} \mathrm{O}_{3}-\mathrm{Na}_{2} \mathrm{O}-\mathrm{B}_{2} \mathrm{O}_{3}-\mathrm{Bi}_{2} \mathrm{O}_{3}$ glasses using MCNPX Monte Carlo code, Materials Chemistry and Physics. $223,209-219$. doi.:10.1016/j.matchemphys.2018.10.064, (2019).

42. I.S. Mahmoud, S.A. Issa, Y.B. Saddeek, H.O. Tekin, O. Kilicoglu, T. Alharbi, M.I. Sayyed, T.T. Erguzel, R. Elsaman, Gamma, neutron shielding and mechanical parameters for lead vanadate glasses, Ceramics International. 45, 14058-14072. doi: 10.1016/j.ceramint.2019.04.105. (2019).

43. H.O. Tekin, E. Kavaz, E.E. Altunsoy, O. Kilicoglu, O. Agar, T.T. Erguzel, M.I. Sayyed, An extensive investigation on gamma-ray and neutron attenuation parameters of cobalt oxide and nickel oxide substituted bioactive glasses, Ceramics International. 45, 99349949. doi:10.1016/j.ceramint.2019.02.036. (2019).

44. G. Susoy, Effect of $\mathrm{TeO}_{2}$ additions on nuclear radiation shielding behavior of $\mathrm{Li}_{2} \mathrm{O}-\mathrm{B}_{2} \mathrm{O}_{3}-\mathrm{P}_{2} \mathrm{O}_{5}-\mathrm{TeO}_{2}$ glass-system, Ceramics International, 46 (3), 3844-3854, doi:10.1016/j.ceramint.2019.10.108. (2019). 